\title{
Disciplinary Power, Surveillance, and the Docile Body in Mark Dunn's Ella Minnow Pea
}

\author{
Hasanain Riyadh Abdulzahra*, Zainor Izat Zainal, Mohamed Ewan Awang and \\ Hardev Kaur Jujar Singh \\ Department of English, Faculty of Modern Languages and Communication, Universiti Putra Malaysia, 43400 \\ Serdang, Selangor, Malaysia
}

\begin{abstract}
Power in contemporary society is a prominent feature in literary works, especially in postmodernist literary works. Mark Dunn is an American novelist who deals with the subject of power prominently in his works, especially his first novel Ella Minnow Pea (2001). While previous studies on Dunn's Ella Minnow Pea focused on aspects of violence, sexuality, and psychological aspects of power, this study concentrates on disciplinary aspects of power, such as surveillance, which is used to subjugate subjects without the use of violence to transform them into productive, docile bodies. The study explores Ella Minnow Pea through Foucault's concept of disciplinary power, surveillance, and docile body. In Foucault's view, disciplinary power is used as a conversion method to force individuals into submission to authority characterised by conformity and obedience, or docility. The study examines power manipulation, disciplinary practices, and the effectiveness of surveillance as methods for converting people into productive docile bodies and how the novel achieved this result. In addition, it delves into the characters' responses in the novel to these machinations, which ultimately reveal that the negative impacts of repressive disciplinary power contrast with the benefits anticipated by the authoritarian state. This study provides a valuable insight on the use of Foucauldian concepts in literary criticism as the concepts chosen for this analysis have not previously been applied to this text.
\end{abstract}

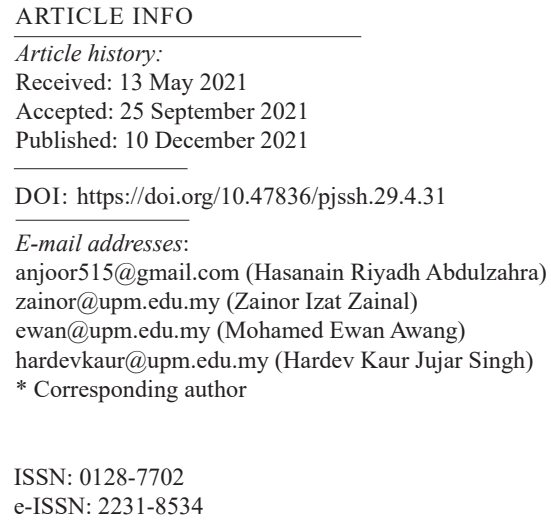

Keywords: Disciplinary power, docile body, Ella Minnow Pea, Foucault, surveillance

\section{INTRODUCTION}

Due to his dexterity and prolific production of novels and plays, Mark Dunn has been known as one of the most pivotal American writers of the late twentieth century until our 
present day. An American novelist, most of the prevalent themes of his works have been totalitarianism, power, resistance, freedom of speech, and dystopia. Mark Dunn was born in Memphis, Tennessee. He studied film at Memphis State University and then pursued a graduate degree in screenwriting at the University of Texas. He moved to New York in 1987 and worked in the New York Public Library while creating plays. Since then, Mark Dunn has written more than 25 full-length plays. Belles and Five Tellers Dancing in the Rain have been produced worldwide, and Dunn has also won several national screenwriting awards. Ella Minnow Pea, published in 2001, was Dunn's debut novel. Dunn has also written six other novels: Welcome to Higby (2002), Ibid: A Life (2004), The Calamitous Adventures of Rodney And Wayne (2009), Under the Harrow (2010), American Decameron (2012), We Five (2015).

Dunn draws on the history of many totalitarian and theocratic regimes in Ella Minnow Pea, such as the Soviet Union under Joseph Stalin, Nazi Germany under Adolf Hitler, the People's Republic of China under Mao Zedong, and the Jin Dynasty's Korea. Countries whose governments are controlled by religious leaders such as Iran and Saudi Arabia also fall into the category of theocratic totalitarianism. These regimes are characterized by dictatorship and tyranny. All political institutions and education serve a specific goal, and regardless of the cost, any obstacles to achieving this goal will be removed. As a result, individual freedoms are often restricted, and governments are given broad freedoms to carry out their goals. Dissent is usually branded evil, and internal political differences are not allowed. Thus, Nollop Island is the setting of the novel and falls under theocratic totalitarianism.

Dunn's Ella Minnow Pea examines betrayal and mistrust under totalitarian governments, in the same vain as Margaret Atwood's Handmaid's Tale, Shirley Jackson's short story The Lottery, and George Orwell in 1984 and The Animal Farm. Charles (2001) credits Dunn's Ella Minnow Pea as being the first 21st-century political satire. He referred to the novel as a progressive fable that could disrupt the market. Charles further described the novel as a cross between a crossword puzzle and a witty political allegory.

In Dunn's Ella Minnow Pea, the characters are citizens of a disciplinary society ruled by an authoritarian regime. The disciplinary society refers to a society where one becomes a docile body due to threat or constant surveillance of power (Doolin, 1998). The setting of the novel is the island of Nollop, situated off the South Carolina coast. The island's government, the High Council, implements draconian restrictions on using certain English alphabet characters in writing by its citizens, curtails freedom of speech, and subjects the residents to constant surveillance, including its educational institution setting. In addition, the government establishes penalties for using the banned alphabetical letters, censuring the offenders publicly for their first violation of the ban, punishing them for their second offence, and following that, exiling them from the island. Dunn 
illustrates these mechanisms of power that exert control over the characters in detailed depictions of life in a disciplinary society.

As can be gathered from the novel, Dunn views schools as disciplinary apparatuses dedicated to the processes of control and homogenisation of society. This notion is exemplified in institutionalisation norms of behaviour and cultural identity enforced through repetitive coercive practices. Dunn reveals the use of surveillance as the main method for changing individuals into docile bodies. Surveillance is present virtually everywhere, especially in prisons, and schools, where individuals are effectively transformed into docile bodies under the gaze of educational institutions.

Foucault has postulated that methods of disciplinary power are developed to facilitate the observation of all aspects of people's lives to make them more productive and profitable. He further explains that discipline regulates both the physical and mental aspects of individuals to produce "subjected and practised bodies, 'docile' bodies" (Foucault, 1995, p. 138). According to Foucault, disciplinary control is developed gradually in governed individuals so that they eventually become completely obedient to the power structure of the society.

Foucault claims that persistent surveillance and monitoring are essential to achieving the intended docile body effect. According to him, disciplinary power "centres on the body, produces individualising effects, and manipulates the body as a source of forces that have to be rendered both useful and docile" (Foucault,
1995, p. 249). Foucault considers the normalising effect of disciplinary techniques an important and productive means of reforming individuals and submits that efficacious submissiveness may be achieved by implementing these methods. Disciplinary methods are thus effective in preparing the body for economic exploitation. Therefore, the purpose of the docile body technique wielded by the disciplinary power structure is the production of practised, subjugated, and useful bodies. However, while the docile body method enhances the body's abilities useful in economic pursuits, other politically important abilities are diminished in favour of obedience.

Rook (2016) noted that surveillance, unlike torture or didactic play, is not used to threaten or provide insight into moral behaviour but rather as a subtle means of training subjects by altering modes of behaviour. This training comprises several aspects, the first of which is to acquire minutely detailed information on subjects that is updated constantly and used as a basis upon which to test the surveilled subjects. If the long-term goal of effecting normality is not needed, but rather more average aims for behaviour formation, rewards and penalties may be implemented to motivate subjects to conform to the desired behaviour. However, training systems involving interventions such as these require management by trained experts in behavioural sciences to gradually achieve normalisation aims.

The novel depicts the disciplinary power of the totalitarian High Council government. The High Council restricts all 
aspects of life on Nolop Island and brings it under its authority and surveillance. Dunne tries in Ella Minnow Pea to reveal how restricting freedom of expression interferes with educational institutions' work. Constant monitoring of citizens is part of totalitarian regimes and even governments headed by extremist religious parties. The novel portrays the council's manipulation of power and disciplinary practices to normalise and control individuals who are confined and subjected to surveillance by the authorities. Thus, this study examines the effectiveness of disciplinary power, surveillance, and power manipulation as methods for converting people into productive docile bodies and the extent to which this result is achieved in the novel. Before proceeding further, a brief review of the literature on Dunn's novel, Ella Minnow $P e a$, is needed.

\section{LITERATURE REVIEW}

\section{Critical Studies on Ella Minnow Pea}

Mark Dunn's novel Ella Minnow Pea: A Novel in Letters (2001; henceforth, Ella Minnow Pea) has been the subject of detailed research in various academic disciplines. These studies have greatly focussed on the novel's theme of dystopian power. Lorber (2016), for example, compared Ella Minnow Pea with Bradbury's Fahrenheit 451 and Orwell's Nineteen Eighty-Four, finding that although the novels share the commonality of dealing with the political power, violence, physical torture, and social issues resulting from the abuses of totalitarian regimes, Ella Minnow Pea stands out by doing this through employing a distinctive epistolary narrative technique. This technique effectively conveys the protagonists' awareness through the epistles (i.e., letters) resulting in a taught relationship between the reader and the narrative. In this way, the novel is elevated above other dystopian novels to become a rarity in the narrative fiction of this genre. Although the study explored political power, physical torture and social issues that resulted from the abuses of despotic regimes, it has neglected the disciplinary power that prevails and its effect in converting the human being into an obedient body.

Bauer's (2018) analysis of Ella Minnow $P e a$ was approached from a different perspective. He referred to the novel's narrative as lipogramatic, as the authoritarian government, known as the High Council, prohibits letters of the alphabet from being used in any correspondence between the citizens of Nollop. This practice is seen as akin to other types of restriction on productivity and communication commonly practised by dictatorial regimes. The novel's narrative depicts the effects of a political dystopia on the preservation and expansion of human knowledge and the freedom and ability to communicate. Thus, the study shows the importance of language in subjecting people and converting them into obedient selves. However, the study did not use other techniques that power employs to convert the people into obedient bodies, such as the art of distribution, the control of activity and normalisation. These techniques could significantly affect the subjects in educational institutions. 
Malin (2003) ran psychoanalytical research trying to analyse, demonstrate, and represent the mental distortions in Ella Minnow Pea. She also examined the pervasive paranoia of the novel, observing how danger is omnipresent in the novel and the connection between the language and culture of the characters and the threats with which they are confronted. Malin draws parallels between the novel and the early American and French authors and filmmakers Georges Perec, Harry Mathews, Raymond Roussel, and Walter Abish. Malin (2003) also explored the themes of power and sexual relations in Ella Minnow Pea, noting the narrative's depiction of the efforts of the ruling High Council to exert domination over all the written correspondence between the citizens of Nollop. He further discussed the extension of the council's control to include the sexual relations among the island's populace and this pretext of power becoming a justification for sexual violence. It exemplifies abuse to satisfy the desires of the powerful. When laws exacting harsh punishments for disobedience are enacted, Nollop's citizens become fearful of attempting a revolt as it would be met with horrific reprisals. Thus, the study explored the sexual violence caused by domination and observation that the government exert on the sexual relations of Nollop people yet failed to underscore the disciplinary practices and the constant surveillance that power imposes on educational institutions and its effect on students and teachers.

The notion of totalitarian power is introduced in the first letter in the narrative of Ella Minnow Pea. Anderson et al. (2016) observed that the subject of tyranny is brought forward through the protagonist Ella's expression of concern over the council's banning of certain alphabetical letters when she affirms, "We slowly conclude that without language, without culture - the two are inextricably boundexistence is at stake" (Dunn, 2002, p. 4). The study explored the effect of eliminating some alphabetical letters from the language on human communication and knowledge. However, the study did not address the restriction of using some letters in the educational institutions and the disciplinary practices such as surveillance and their consequences on productivity of education and behaviours of teachers and students.

Some research has also been conducted on some other novels with reference to power through Foucault's theory. For example, Isik (2020) examined Dave Eggers' The Circle; he argued that disciplinary power that the novel prevails makes the people control and govern themselves as if they were followed by an invisible eye. Moreover, Isik asserts that surveillance as the power of disciplinary society "increases productivity as people, who feel under observation, work efficiently" (2020, p. 155). In contrast, Tian describes the disciplinary power of the novel 1984 and asserts that the power of surveillance "take advantage of people's fear to break them and control their emotional minds and this fear could lead people into maniac states and melancholia" (2018, p. 50). Furthermore, Tian (2018) expounds that the emotional consequences 
of imprisonment caused by discipline monitoring are similar to symptoms of madness. Although these studies have been conducted on power through Foucault's theory, they have generated controversial discussion on how the power of discipline converts the human into a productive docile body. They are descriptive reviews and need a critical review. Therefore, in this study, we investigate the impact of disciplinary practices on the characters subjected to surveillance and observation power in society's disciplinary institutions in Ella Minnow pea.

From the above review of literature, it may be concluded that studies on Ella Minnow Pea have discussed power from various perspectives, including dystopia, lipogramatic and epistolary narrative, sexual violence, totalitarianism, and psychoanalytical. However, none of the studies has employed Foucault's views of disciplinary power, surveillance, or the docile body. While previous studies focused on the political aspects of power, violence, physical punishment, sexual relations, the restriction and eliminating some alphabetic letter of the language from being used among people for subjugating the entire society, this study concentrates on another sort of power in the novel which is called disciplinary power. It depends on surveillance in the subjection of the people. The disciplinary power also employs sophisticated techniques such as the art of distribution, the activity control, normalisation and individualising the bodies to convert the entire society into obedient. To analyse such sort of power in Ella Minnow
Pea, we employ Foucault's theory of disciplinary power, surveillance and docile body to understand how disciplinary power works in contemporary society that the novel depicts in the political and educational institutions of Nollop society and what is the impact of disciplinary power on the subjects in the educational institutions. Therefore, this study examines power manipulation and the disciplinary practices inflicted on the teachers and students of the educational institution in the dystopian society depicted in the novel Ella Minnow Pea.

\section{METHODOLOGY}

A close reading of the text has been adopted to investigate and answer the research question. We have related Ella Minnow $P e a$ to the study of disciplinary power in the characters of the novel. The analysis of the novel focuses on the main characters subjected to the manipulation of the body through various systems of control. Mittie, for example, is the protagonist and one such character subjected to the discipline of the High Council in the novel's educational setting. Schools are seen by Foucault (1995) as essential disciplinary institutions for the management, control, and homogenisation of students to transform them into productive bodies. Through this concept of disciplinary power and surveillance, we explore the aspects of power manipulation detailed in the novel intended to transform humans into docile bodies. We explore the effect of disciplinary practices on the characters in the novel, such as Mittie and Ella, in the educational setting. 
A qualitative study is conducted through textual analysis of Ella Minnow Pea. The analysis will be intrinsic. We explain how the characters produce vivid, controlled, manipulated, and surveillance images of Nollop society's disciplinary intuitions, such as a school in abusive and totalitarian control systems. We have also highlighted the High Council's techniques to subject and convert the characters in the novel (i.e., Mittie and Ella) into productive and obedient bodies, "docile bodies". The characters reveal their discontent with these disciplinary practices through nightmares, fear of being observed or monitored, and repetitive re-enactments.

Foucault defines disciplinary power as "a type of power, a modality for its exercise, comprising a whole set of instruments, techniques, procedures, levels of application, targets; it is a 'physics' or an 'anatomy of power, a technology" (1995, p. 215) that utilise to train, regulate, and control the individuals in different institutions of contemporary society such as schools, hospitals, families, factories. In the Foucauldian view, social institutions use power to exert control over training individuals for roles within their establishments. Thus, schools in contemporary society rely on many methods of regulating students' behaviour and directing it in compliance with the needs of the institutions. This process, according to Foucault, results in the creation of docile bodies to do the bidding of those in power (Leitch et al., 2018). Thus, Foucauldian theory rejects the view that power is necessarily wielded by particular individuals or institutions and holds that it is distributed among the systems and members of society. However, Foucault regards diverse power systems as productive entities that promote the types of behaviour they desire. Thus, he argues:

We must cease once and for all to describe the effects of power in negative terms: it 'excludes,' it 'represses,' it 'censors,' it 'abstracts,' it 'masks,' it 'conceals.' Power produces; it produces reality; it produces domains of objects and rituals of truth. The individual and the knowledge that may be gained of him belong to this production. (Foucault, 1995, p. 194)

Manley et al. (2012) suggested that authority through surveillance constantly targets individuals through distributed networks, and those in power with privileged status may be situated outside the scope of those networks. Furthermore, this mode of power does not rely on domination but instead employs disciplinary techniques to increase the productivity of individuals. Foucault alludes to individuals' relations within the contexts associated with these power dynamics in his assertion that "while the human subject is placed in relations of production and signification, he is equally placed in power relations that are very complex" (1995, p. 47). Thus, individuals are classified, shaped, and individualised by the power relations surrounding them to enhance their utility, efficiency, and the economic value of their actions. 
In Ella Minnow Pea, the characters such as Mittie and Ella are placed constantly under surveillance, controlled and monitored wherever they go and whatever they do. We have highlighted that the characters in the novel live in a life where daily worry about acts of punishment and violence, not only directed towards themself but also towards people they love and care for. Picture a life where they always live in fear of doing something wrong, of breaking an unwritten rule. Thus, through Foucault's concept of surveillance, we analyse how the characters deal with the High Council (antagonist) exert over them in social institutions (Mittie's school). We also analyse how the characters (i.e., Mittie and Ella) reaction to the constant monitoring and observation in Nollop society.

Nollop's citizens are compelled to be complicit in the methods of control that are deployed against them. These methods may best be explained in reference to Foucault's "panopticism" concept. Jeremy Bentham's notion of the Panopticon extends, a prison encircling a surveillance watchtower at its centre. As the prison cells are arranged along the walls encircling the watchtower, the guards have a vantage point where they can see everything happening in prison surrounding them. The theory of power behind this concept is that the inmates will become responsible for their behaviour as they never know when they may be monitored. Thus, they are compelled to act as if they are being observed even when they are not. As explained by Foucault, the
Panopticon is analogous to the domination of people by a system of disciplinary power:

He who is subjected to a field of visibility, and who knows it, assumes responsibility for the constraints of power; he makes them play spontaneously upon himself; he inscribed in himself the power relation in Panopticism which he simultaneously plays both roles; he becomes the principle of his subjection. (1995, pp. 202-203)

As this study considers the role of the body in the disciplinary society depicted in Ella Minnow Pea, it is important to discuss the importance of the docile body to the disciplinary authorities. The body is the focal point of the disciplinary systems of contemporary societies, as noted by Foucault in his assertion that "what is essential in all power is that ultimately its point of application is always the body" (Foucault, 2008, p. 14). Therefore, the analysis will discuss the techniques of disciplinary power utilised in the novel to control and regulate the human body. We adopt the Foucauldian concept of the docile body in our textual analysis investigating Dunn's depictions of the conversions of the novel's protagonists into obedient, productive bodies through the art of distribution, control over activities, and the forces of normalisation. We thus apply the Foucauldian concept of the docile body in our assessment of the effects of the systems of control on the bodies of the novel's characters. 


\section{RESULTS AND DISCUSSION}

\section{Mitti's School as a Disciplinary} Apparatus in Ella Minnow Pea

Dunn's characters are presented as having dismissive attitudes about their school. The High Council's policy of banning alphabetical letters decreases intellectual expression in the education system. Furthermore, the government expanded the policy to burning books containing banned letters, and the resulting deprivation further diminishes the value of the written word in society. The schools are given instructions that no one can choose what books they want to read, which affects the teachers. Thus Mittie, a schoolteacher, is faced with a dilemma when preparing lesson plans without using the banned letters. Her reaction to this is revealed in the following text from the novel:

I did not tell you how the slip occurred. She was teaching arithmetic and made mention of a sum of eggs. Twelve eggs to be exact. And described them using a word no longer at our disposal. A right and proper word in times gone by. How does, in any fair and logical way, the Council expect us - all of us - not to make such a simple and innocent slip now and then! (Dunn, 2002, p. 33)

It reveals that Mittie is aware of the homogenisation the government is aiming for in Nollop's schools. It also explains the council's restrictive disciplinary tactics forcing teachers to alter their lesson plans to comply with the new laws. Teachers and students are expected to follow these conventions to become homogenised, sharing the same desires and anticipations. Thus, the government intends that the schools produce socially accepted subjects in docile bodies lacking opportunities to resist.

Power relations can extend beyond the domination of individuals, body and soul, to eliminate personal identity and free speech (Foucault \& Gordon, 1980). The characters in Ella Minnow Pea are thus deprived of their rights by the High Council. They are denied any right to express opinions and threatened with harsh penalties for doing so. Even a member of the High Council, William Creevy, is removed from the council for criticising the government's repressive policies. Subsequently, Creevy violates the disciplinary policies and is then whipped and banished from Nollop:

Young Master Creevy was sent away today. When the flogging had ended, he allegedly (I was not there) raised his head and let spew forth a long repetitive illicit-letterpeppered tirade against the L.E.B. officers who had administered his punishment. (Dunn, 2002, p. 25)

The excerpt illustrates the severity of punishment imposed on anyone who would dare disagree with or criticise the government. The threat of such consequences inspires fear in the population, compelling their obedience to the High Council's disciplinary system. 
In Ella Minnow Pea, this technique of disciplinary power is represented as repressive and not useful against individuals. As a result of their fear of reprisals, the teachers and students appear to become nonproductive, and they are forced to follow new disciplinary norms to normalise them. However, Mitte and Ella are not made docile in the face of these challenges as they have realised the purpose of the High Councils' disciplinary policies.

\section{Surveillance in Ella Minnow Pea}

Bourke et al. (2013) explain the reason for the effectiveness of surveillance as a means of subjugating the body: "It is the fact of being constantly seen ... that maintains the disciplined individual in his subjection" (p. 89). For example, the students depicted in Ella Minnow Pea have been identified as social outcasts with anti-social and self-destructive tendencies; therefore, they are placed under constant surveillance in the school. The educational gaze (i.e., constant surveillance) is used to reshape the students' behaviour to comply with established disciplinary norms. The effects of surveillance ultimately extend to the whole of Nollop society. In the Foucauldian sense, people self-regulate their activities, which effectively changes them into obedient individuals or docile bodies. The prevalence of surveillance can thus normalise behaviour and is supported to great success by the stratification of mind control, machine surveillance, and other disciplinary practices. Moreover, Foucault (1995) asserts that the authoritarian gaze has been influential in regulating, monitoring, and obtaining information about individuals to maintain control.

Through persistent monitoring, the students and teachers are transformed into obedient, robotic entities under the control of the system. Any individual who does not conform to the power system's requirements is considered irregular. The disciplinary authorities exploit individual's incapable of thinking things through to understand themselves or make their own decisions, who control them at will. Therefore, this process eventually normalises them into docile bodies.

Surveillance technology is presented in Ella Minnow Pea as being used for another purpose, as well. The High Council establishes a surveillance centre to dominate the residents of Nollop so that they think, write, and behave as they are told. Thus, the centre is equipped to examine and control the correspondence in letters sent by Nollop's citizens. If banned characters of the alphabet are detected in a letter, the person who wrote it is punished. The extent of this surveillance is discussed in letters sent to Ella by her mother:

While you were at the prison, attempting with your Aunt Mittie yet again to get in to see Tassie, men who were sent here to see me got themselves into our sorry with little struggle at all. They were sent to interrogate me-the grilling about the now exonerate anti-high-priestly movement... It's a weeping shame. Why, I am not 
even given enough time to gather my things! All my possessions, your Pop's possessions are yours now, I suppose. Preserve them. Preserve our memory. I wish you to stay. You must stay. Maintain the struggle.

(Dunn, 2002, p. 110)

Subsequently, Ella is charged by the council for using a banned letter in her writing. Faced with the choices of exile from Nollop, imprisonment, or torture as punishment, she chooses prison. The authorities launch a full investigation of Nollop's society, increasing the oppression of the fearful citizenry and quashing their freedoms and rights at all levels, making matters worse. These characteristics make Ella Minnow Pea stand out among dystopian novels for its revealing portrayal of government oppression through surveillance as a tool of manipulation and control.

In the novel, the people working for the High Council are aware of the surveillance and allow no one to claim any rights. Individual freedom of expression is effectively abolished, and those whose speech is considered illegal are punished and/or imprisoned. The council thus has absolute control over Nollop's population. Ella, in the following passage, reveals the extent of the council's disciplinary power:

I cannot help you. Not now. Please tell Tassie: Rory is gone. It began this way: brash Council representatives, upon reaching his northern acreage, gave him papers that gave them authority to appropriate his property. No reason was given other than: "It is the Council's wish." (Dunn, 2002, p. 121)

Like a panopticon prison, the residents of Nollop are constantly under the gaze of the authoritarian powers of the High Council, and any infractions of the council's regulations are met with severe penalties. Thus, although the purpose of the island's institutions and rules is to transform the citizens, such as the schoolteachers and students, into docile bodies, obedient to the government, violations of the rules by the public and abuse of power manipulation represent failures of the system to achieve its goals. Ultimately, the system's failure is in contrast with Foucauldian theory in that the actions of a severe regimen can lead to catastrophic results. There may be no positive results.

\section{The Art of Distribution, Enclosure, the Control of Activity and Normalisation in Ella Minnow Pea}

A disciplinary society mainly concentrates on the demarcation between regular and irregular bodies. Regular bodies are useful, while irregular, aberrant bodies that violate societal norms and cannot conform are isolated from regular or normal bodies to be trained for conformity. The first step in this process is usually to confine them in structures dedicated to this purpose. This approach places aberrant members of society, such as prisoners, in a social multiplicity. In Ella Minnow Pea, Dunn depicts this by using an encirclement 
approach to confine non-conformant citizens in facilities such as the L.E.B. and the Nollop schools. There, the council imposes operational rules that differentiate the normal bodies that benefit them from the aberrant bodies that must be normalised. Mittie and her students cooperate with the government rulings and thus represent docile or regular bodies. However, Rederick Lyttle, a High Council member described as "the least moronic of the bunch" (Dunn, 2002, p. 109), is identified as abnormal for opposing a government proposed shorter pangram to replace Nevin Nollop's. Thus, Dunn depicts the effectiveness of the High Council's mechanism of encirclement in its use against Mittie, who is confined on Nollop, and Rederick Lyttle, who is ultimately exiled from Nollop.

In Discipline and Punish (1995), Foucault discusses the human body's need for enclosure within a place of heterogeneity about others. It is described as a protected space of "disciplinary monotony" (Foucault, 1995, p. 141), closed in upon itself. Such a segregated space can be useful in facilitating the normalisation of irregular individuals. Foucault has also expounded the encirclement of the body in special architecture as a method "defined to correspond not only to the need to supervise, to break dangerous communications, but also to create a useful space" (p. 143) for the initial steps of exerting power over prisoners. However, Foucault (1995) notes this is insufficient on its own to convert the incarcerated into docile bodies. Additional tools and techniques are needed to subjugate individuals and exert control over their bodies to enslave them to the power structure.

One example of this is that the subjugation of the human body, as theorized by Foucault (1995), may be accomplished through the activity control. In Ella Minnow $P e a$, the High Council uses timetables to control activity. It is a time-proven method of ensuring that people spend their time in activities of benefit to society or its service. Furthermore, the distribution of time is designed to control the activities of obedient prisoners or students so that their time is well invested within disciplinary spaces. The utilisation of time is thus optimized to improve inmates' routines and ultimately make them beneficial to the disciplinary authorities. This exploitation of time is illustrated in the novel when Mittie is prevented from visiting her son Tassie in prison:

They will not let me into the prison to see you. I have spent the entire post noon ... Waiting here on the prison's visitors' lawn to see you. Waiting. Waiting. They tell us nothing ... operate in ways that are not at all as we are. We're anything to happen to you, what then? (Dunn, 2002, p. 109)

The above passage indicates that Mittie understands that the guards have control over prisoners' time. She further explains that the High Council similarly orders students and school staff members to submit timetables to exert control over their activities. 
Normalisation is the ultimate goal in a disciplinary society's regulation of individuals. Norms are imposed on individuals to force their acceptance of and compliance with the system. Thus, educational institutions attempt to homogenise teachers' attitudes in accordance with societal expectations. Foucauldian theory regards schools as analytical apparatuses useful in developing normalising influences (Foucault, 1995). Established disciplinary methods are intended to normalise the behaviour of students ultimately. This process depends on surveillance as the main method for the subjugation of teachers and students. Foucault explains the significance of this normalisation method as follows:

It traces the limit that will define the difference concerning all other differences, the external frontier of the abnormal.... The perpetual penalty that traverses all points and supervises every instant in the disciplinary institutions compares, differentiates, hierarchized, homogenizes, excludes. In short, it normalizes. (1995, p. 183)

When the normalisation process exceeds sensible limits, individuals may become dehumanised by the coercion to follow system requirements. For example, institutions may attempt to benefit from presenting improper ideas as appropriate. This approach to homogenisation may be attempted through enacting laws and regulations, producing mass media such as films or advertising. The process trains individuals to be docile bodies of benefit to those in power. Individuals thus become mere spectres of humanity, behaving as they are directed. For example, the High Council in Ella Minnow Pea utilises several techniques and harsh treatment to ensure their control over students, and thus none dare to violate government directives. The normalisation of teachers and students regarded as criminals presents a challenge to the council. It requires various disciplinary techniques in many phases to accomplish, and it usually fails. This failure is depicted in the novel when many students and teachers resign from the school as they cannot function there and would be punished if they failed to cooperate with the council.

Mittie, for example, is constantly under supervising surveillance; however, she remains true to herself. She rejects the High Council's attempts at subordination and subjugation and is not normalised. She, therefore, tries to circumvent the law banning alphabetical letters essential for communication and education. Mittie thus opposes the draconian rules imposed to transform people into obedient, docile bodies and make the students and teachers into robots or ghosts of their former selves.

According to Foucault (1995), disciplinary control within communities is usually exerted through disciplinary organisations and their operatives. Schools are one such type of disciplinary organisation, wherein an analogy by Foucault, docile students are comparable to soldiers in their expected obedience to the rigid disciplinary order of a school: 
Place[s] the bodies in a little world of signals to each of which is attached a single, obligatory response: it is a technique of training, of dressage, ... he is ordered to do; his obedience is prompt and blind; an appearance of indocility, the least delay would be a crime. The training of schoolchildren was to be carried out in the same way: few words, no explanation, a total silence interrupted only by signals bells, clapping of hands, gestures, a mere glance from the teacher, or that little wooden apparatus used by the Brothers of the Christian Schools. (1995, p. 166)

Thus, schools perform a crucial function in producing docile students with soldier-like obedience. However, as discussed previously, Mittie opposes the High Council's policies and methods to homogenise individuals. Her opposition is the most striking in the novel as her obvious disobedience in the face of the High Council's disciplinary plans is so definite.

Mittie endures the High Council's rules until they become intolerable. It happens during a classroom lesson as she attempts to explain to students that 12 eggs equal a dozen and commits the crime of using the forbidden letter $Z$, which a student, Timmy Towgate immediately notices. The frustration of this situation leads her to resign from her job:

I cannot teach. Without that grammatical unifier. It is impossible.
I plan to resign tomorrow. Semicolons are simply not an option. These youngsters are only seven! ... My brain throbs. I have a hangover. Far too much wine last night. The wine. Plus, the loss of that grammatical unifier. It is all too much. Forgive me for my weakness. (Dunn, 2002, p. 52)

Mittie feels compelled to leave her teaching job as the stress of possibly using a forbidden letter or committing some other infraction has become too much to bear. Therefore, after commiting a third infraction, she decides to leave Nollop and Nate Warren and her daughter. Despite the dire circumstances of the Nollopian citizens, Mittie is the only character to take a stand and leave the island. The execution of Dr Mannheim for his refusal to accept exile was a strong influence on her decision to leave. She chooses freedom over oppression, demonstrating her individual power to choose her fate and break free of the oppression of disciplinary rule. Thus, Dunn offers a positive take on the rebellious few in society who confront authority and challenge societal norms and laws many consider to be inviolable.

The power manipulation, and disciplinary practices have been examined in other novels such as Dave Eggers' The Circle (2013) through Foucault's lens. For example, Isik (2020) examined The Circle with reference to the power manipulation and disciplinary practices exerted on the subjects in the disciplinary setting named the circle (i.e., A big company in the 
US). To Isik, the disciplinary power in modern society makes the people control and govern themselves as if they were followed by an invisible eye. Moreover, Isik asserts that surveillance as the power of disciplinary society "increases productivity as people, who feel under observation, work efficiently" (2020, p. 155). Likewise, according to him, disciplinary power "centres on the body, produces individualising effects and manipulates the body as a source of forces that have to be rendered both useful and docile" (p. 249). On the other hand, Foucault considers the normalising effect of disciplinary techniques an important and productive means of reforming individuals and submits that efficacious submissiveness may be achieved by implementing these methods. However, in this study, we show that power manipulation, surveillance and docile bodies are disciplinary practices and techniques that work on repressing the subjects in the disciplinary setting rather than reforming them and converting them into productive and obedient subjects.

\section{CONCLUSION}

This study examined the implementation and effects of power manipulation and disciplinary practices on the characters of Ella Minnow Pea, emphasising the teachers and students of the educational facility depicted in the novel. The analysis revealed that although disciplinary methods could be employed to homogenise and normalise individuals, transforming them into docile (obedient) beings, they are not proven to be advantageous to an appreciable level.
Even though it is common for educational institutions to increase the potential of teachers and students' by utilising disciplinary techniques in training and educational programmes, no such training is mentioned in Ella Minnow Pea. Instead, the students and teachers are compelled into silence through constant surveillance. Surveillance is considered the most widely used means of exerting disciplinary power to subjugate individuals, compelling their compliance with disciplinary order and their normalisation to social and working conditions. Dunn depicts characters' discontent with disciplinary methods, particularly when they involve severe punishments such as the execution of Dr Mannheim. The disciplinary strategies represented in the novel are meant for repression rather than treatment as a means of correction or training of the island's community. The repressive docile body technique used in Ella Minnow Pea is proven counterproductive as it is ineffective when used on individuals. Characters in the novel are only compelled to follow disciplinary norms due to their fear of punishment if they do not. The system's failure is proven because neither Mittie nor Ella is made docile despite the threat of punishment.

\section{ACKNOWLEDGMENT}

The first and the corresponding author (Hasanain Riyadh Abdulzahra) would like to express sincere gratitude and appreciation to the co-authors for their continuous support and help in writing this article. 
Furthermore, the appreciation goes to Dr Zainor Izat Zainal for guidance and continuous support. Finally, the Library of UPM for the resourceful information received from the staff.

\section{REFERENCES}

Anderson, C., Goldsworthy, B., \& MacQueen, L. (2016). Finding community in young adult literature. Language Arts Journal of Michigan, 32(1). https://doi.org/10.9707/2168-149x.2154

Bauer, M. (2018). Self-imposed fetters: The productivity of formal and thematic restrictions. Connotations: A Journal for Critical Debate, 27, 1-18. http://www.connotations.de/debate/fetters

Bourke, T., Lidstone, J., \& Ryan, M. (2013). Schooling teachers: Professionalism or disciplinary power? Educational Philosophy and Theory, 47(1), 84-100. https://doi.org/10.1080/00131857.201 3.839374

Charles, R. (2001, October 4). Political satire missing letters, but not wit. The Christian Science Monitor. https://www.csmonitor.com/2001/1004/ p19s1-bogn.html

Doolin, B. (1998). Information technology as disciplinary technology: Being critical in interpretive research on information systems. Journal of Information Technology, 13(4), 301-311. https://doi. org/10.1177/026839629801300408

Dunn, M. (2002). Ella Minnow Pea: A novel in letters. Anchor.

Foucault, M. (1995). Discipline and punish: The birth of the prison. Vintage Books.

Foucault, M. (2008). Psychiatric power: Lectures at the collège de France, 1973-1974 (Vol. 1). Macmillan.
Foucault, M., \& Gordon, C. (1980). Power/knowledge: Selected interviews and writings 1972-1977. Harvester.

Isik, D. (2020). A Foucauldian reading of DAVE Eggers's the circle. Modernism and Postmodernism Studies Network, 1(2), 154-162. https://doi.org/10.47333/ modernizm.2020265884

Leitch, V. B., Cain, W. E., Finke, L., McGowan, J., Sharpley-Whiting, T. D., \& Williams, J. (2018). The Norton anthology of theory and criticism. W.W. Norton \& Company.

Lorber, S. (2016). Paper Lorber. Academia.edu. https://www.academia.edu/36923907/Paper Lorber

Malin, I. (2003). Ella minnow pea: A novel in letters. Review of Contemporary Fiction, 23(2), 1-53.

Manley, A., Palmer, C., \& Roderick, M. (2012). Disciplinary power, the Oligopticon and rhizomatic surveillance in elite sports academies. Surveillance \& Society, 10(3/4), 303-319. https:// doi.org/10.24908/ss.v10i3/4.4281

Rook, O. (2016). Surveillance, regulation and selfhood in George Orwell's 1984 (1949) and Margaret Atwood's The Handmaid's Tale (1985). In Innervate Leading Student Work in English Studies (Vol. 8; pp. 14-28). University of Nottingham. https://www.nottingham.ac.uk/ english/documents/innervate/15-16/02-oliviarook-q33407-pp-14-28.pdf

Tian, S. (2018). George Orwell's 1984 and Peter Weir's The Truman Show under the perspective of Michel Foucault. Journal of Artistic Creation and Literary Research, 6(2), 48-64. https://www. ucm.es/siim/journal-of-artistic-creation-andliterary-research 